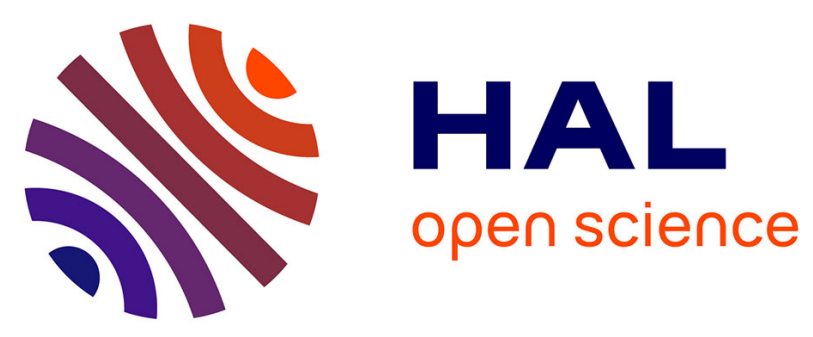

\title{
Strong antigen-specific T-cell immunity induced by a recombinant human TERT measles virus vaccine and amplified by a DNA/viral vector prime boost in IFNAR/CD46 mice
}

Elodie Pliquet, Claude Ruffie, Marie Escande, Jessie Thalmensi, Valérie Najburg, Chantal Combredet, Thomas Bestetti, Marion Julithe, Christelle Liard, Thierry Huet, et al.

\section{- To cite this version:}

Elodie Pliquet, Claude Ruffie, Marie Escande, Jessie Thalmensi, Valérie Najburg, et al.. Strong antigen-specific T-cell immunity induced by a recombinant human TERT measles virus vaccine and amplified by a DNA/viral vector prime boost in IFNAR/CD46 mice. Cancer Immunology, Immunotherapy, 2019, 68 (4), pp.533-544. 10.1007/s00262-018-2272-3 . pasteur-03232227

\section{HAL Id: pasteur-03232227}

https://hal-pasteur.archives-ouvertes.fr/pasteur-03232227

Submitted on 9 Jun 2021

HAL is a multi-disciplinary open access archive for the deposit and dissemination of scientific research documents, whether they are published or not. The documents may come from teaching and research institutions in France or abroad, or from public or private research centers.
L'archive ouverte pluridisciplinaire HAL, est destinée au dépôt et à la diffusion de documents scientifiques de niveau recherche, publiés ou non, émanant des établissements d'enseignement et de recherche français ou étrangers, des laboratoires publics ou privés. 


\section{Cancer Immunology, Immunotherapy}

\section{Strong antigen specific T-cell immunity induced by a recombinant human TERT measles virus vaccine and amplified by a DNA/viral vector prime-boost in IFNAR/CD46 \\ mice \\ --Manuscript Draft--}

\begin{tabular}{|c|c|c|}
\hline Manuscript Number: & \multicolumn{2}{|l|}{ CIIM-D-18-00105R2 } \\
\hline Full Title: & \multicolumn{2}{|c|}{$\begin{array}{l}\text { Strong antigen specific T-cell immunity induced by a recombinant human TERT } \\
\text { measles virus vaccine and amplified by a DNA/viral vector prime-boost in IFNAR/CD46 } \\
\text { mice }\end{array}$} \\
\hline Article Type: & \multicolumn{2}{|l|}{ Original Article } \\
\hline Funding Information: & $\begin{array}{l}\text { Association Nationale de la Recherche et } \\
\text { de la Technologie } \\
(2012 / 0152)\end{array}$ & Dr. Elodie PLIQUET \\
\hline Abstract: & \multicolumn{2}{|c|}{$\begin{array}{l}\text { Cancer immunotherapy is seeing an increasing focus on vaccination with tumor- } \\
\text { associated antigens (TAAs). Human telomerase (hTERT) is a TAA expressed by most } \\
\text { tumors to overcome telomere shortening. Tolerance to hTERT can be easily broken } \\
\text { both naturally and experimentally and hTERT DNA vaccine candidates have been } \\
\text { introduced in clinical trials. DNA prime/boost strategies have been widely developed to } \\
\text { immunize efficiently against infectious diseases. We explored the use of a recombinant } \\
\text { measles virus (MV) hTERT vector to boost DNA priming as recombinant live } \\
\text { attenuated measles virus has an impressive safety and efficacy record. Here, we show } \\
\text { that a MV TERT vector can rapidly and strongly boost DNA hTERT priming in MV } \\
\text { susceptible IFNAR/CD } 46 \text { mouse models. The cellular immune responses were Th1 } \\
\text { polarized. No humoral responses were elicited. The } 4 \text { kb hTERT transgene did not } \\
\text { impact MV replication or induction of cell mediated responses. These findings validate } \\
\text { the MV TERT vector to boost cell-mediated responses following DNA priming in } \\
\text { humans. }\end{array}$} \\
\hline Corresponding Author: & \multicolumn{2}{|l|}{$\begin{array}{l}\text { Elodie Pliquet, Ph.D } \\
\text { INVECTYS/Institut Pasteur } \\
\text { Paris, FRANCE }\end{array}$} \\
\hline \multicolumn{3}{|l|}{$\begin{array}{l}\text { Corresponding Author Secondary } \\
\text { Information: }\end{array}$} \\
\hline Corresponding Author's Institution: & \multicolumn{2}{|l|}{ INVECTYS/Institut Pasteur } \\
\hline \multicolumn{3}{|l|}{$\begin{array}{l}\text { Corresponding Author's Secondary } \\
\text { Institution: }\end{array}$} \\
\hline First Author: & \multicolumn{2}{|l|}{ Elodie PLIQUET, Ph.D } \\
\hline \multicolumn{3}{|l|}{ First Author Secondary Information: } \\
\hline \multirow[t]{11}{*}{ Order of Authors: } & \multicolumn{2}{|l|}{ Elodie PLIQUET, Ph.D } \\
\hline & \multicolumn{2}{|l|}{ Claude RUFFIE } \\
\hline & \multicolumn{2}{|l|}{ Marie ESCANDE } \\
\hline & \multicolumn{2}{|l|}{ Jessie THALMENSI } \\
\hline & \multicolumn{2}{|l|}{ Valérie NAJBURG } \\
\hline & \multicolumn{2}{|l|}{ Chantal COMBREDET } \\
\hline & \multicolumn{2}{|l|}{ Thomas BESTETTI } \\
\hline & \multicolumn{2}{|l|}{ Marion JULITHE } \\
\hline & \multicolumn{2}{|l|}{ Christelle LIARD } \\
\hline & \multicolumn{2}{|l|}{ Thierry HUET } \\
\hline & \multicolumn{2}{|l|}{ Simon WAIN-HOBSON } \\
\hline
\end{tabular}


Frédéric TANGY

Pierre LANGLADE-DEMOYEN

Order of Authors Secondary Information:

Author Comments:

Heterologous prime/boost strategies provide exciting opportunities for use in tumor patients because higher immune response to the target antigen can be induced. MV vaccine has impressive safety record.

\section{Additional Information:}

Question

\section{Response}

Please provide one or two short Heterologous prime/boost strategies provide exciting opportunities for use in tumor sentences highlighting what makes your manuscript especially interesting. This patients because higher immune response to the target antigen can be induced. MV vaccine has impressive safety record.

précis is meant for our table of contents and must not exceed 250 characters, including spaces. Please include an identical précis in your manuscript text, following the abstract 
Invectys

Pépinière Paris Santé Cochin

27, rue du Faubourg Saint Jacques

75014 Paris

France

\section{FOR THE REVIEWERS}

Reviewer \#1: The authors have responded to comments in a satisfactory way.

Reviewer \#2: The revised manuscript is substantially improved and therefore I am happy with it being accepted for publication without the need for any further revision.

Response: We are happy that our additional responses and modifications improved the manuscript and were satisfied for you.

\section{FOR THE EDITORIAL OFFICE}

4) "in IFNAR/CD46 mouse model" is not quite correct.

$\rightarrow$ Indeed, "IFNAR/CD46 mice" is more appropriate because there are two different mouse models in this manuscript with IFNAR/CD46 background.

7) Look at your "Author contributions" section.

$\rightarrow$ Done

9) please make sure that both the contents and the English of your entire paper (including all parts) are correct [...] Maybe your co-author Simon Wain-Hobson is a native English speaker who could correct the entire final (!) version.

$\rightarrow$ Done

Best regards,

Elodie Pliquet, $\mathrm{PhD}$

Invectys

Pépinière Paris Santé Cochin

27, rue du Faubourg Saint Jacques

75014 Paris

France

Tel +33 $181800524 / 520$,

Fax +33181800 530

elodie.pliquet@invectys.com 
Strong antigen specific T-cell immunity induced by a recombinant human TERT measles virus vaccine and amplified by a DNA/viral vector prime-boost in IFNAR/CD46 mice

\begin{abstract}
Elodie Pliquet ${ }^{1,2}$, Claude Ruffie ${ }^{3}$, Marie Escande ${ }^{1}$, Jessie Thalmensi ${ }^{1}$, Valérie Najburg ${ }^{3}$, Chantal Combredet ${ }^{3}$, Thomas Bestetti ${ }^{1}$, Marion Julithe ${ }^{1}$, Christelle Liard ${ }^{1}$, Thierry Huet ${ }^{1}$, Simon Wain-Hobson ${ }^{1,2}$, Frédéric Tangy ${ }^{3}$, Pierre Langlade-Demoyen ${ }^{1,2}$
\end{abstract}

${ }^{1}$ Invectys, Pépinière Paris Santé Cochin, Paris, France

${ }^{2}$ Molecular Retrovirology unit, Institut Pasteur, CNRS-URA 3015, Paris, France

${ }^{3}$ Viral Genomics and Vaccination Unit, Institut Pasteur, CNRS-UMR 3965, Paris, France

Corresponding author:

Elodie Pliquet

Invectys, Pépinière Paris Santé Cochin

27, rue du Faubourg Saint Jacques

75014 Paris

France

elodie.pliquet@invectys.com

+33181800524

\title{
ORCID
}

Elodie PLIQUET: 0000-0003-4242-8569

Thierry HUET: 0000-0001-9842-591X

Simon WAIN-HOBSON: 0000-0002-6406-3858

Frederic TANGY: 0000-0002-5937-5654 


\begin{abstract}
Cancer immunotherapy is seeing an increasing focus on vaccination with tumor-associated antigens (TAAs). Human telomerase (hTERT) is a TAA expressed by most tumors to overcome telomere shortening. Tolerance to hTERT can be easily broken both naturally and experimentally and hTERT DNA vaccine candidates have been introduced in clinical trials. DNA prime/boost strategies have been widely developed to immunize efficiently against infectious diseases. We explored the use of a recombinant measles virus (MV) hTERT vector to boost DNA priming as recombinant live attenuated measles virus has an impressive safety and efficacy record. Here, we show that a MV-TERT vector can rapidly and strongly boost DNA hTERT priming in MV susceptible IFNAR/CD46 mouse models. The cellular immune responses were Th1 polarized. No humoral responses were elicited. The $4 \mathrm{~kb}$ hTERT transgene did not impact MV replication or induction of cell mediated responses. These findings validate the MV-TERT vector to boost cell-mediated responses following DNA priming in humans.
\end{abstract}

Key words: Cancer, immunotherapy, hTERT, measles virus vaccine, T-cell responses

\title{
Précis
}

Heterologous prime/boost strategies provide exciting opportunities for use in tumor patients because higher immune response to the target antigen can be induced. MV vaccine has impressive safety record.

$\begin{array}{ll}\text { Abbreviations } & \\ \text { AP } & \text { Alkaline phosphatase } \\ \text { ATU } & \text { Additional transcription unit } \\ \text { BCIP } & \text { 5-Bromo-4-chloro-3-indolyl phosphate } \\ \text { CBA } & \text { Cytometric beads array } \\ \text { MOI } & \text { Multiplicity of infection } \\ \text { MV } & \text { Measle virus } \\ \text { NBT } & \text { Nitro blue tetrazolium chloride } \\ \text { PVDF } & \text { Polyvinylidene fluoride } \\ \text { ROI } & \text { Region of interest } \\ \text { Tg } & \text { Transgenic } \\ \text { TMB } & \text { 3,3',5,5'-Tetramethylbenzidine } \\ \text { Ubi } & \text { Ubiquitin } \\ \text { UCP } & \text { Universal cancer peptide }\end{array}$




\section{Introduction}

Tumors manipulate their microenvironment and the adaptive immune response. With this understanding, immunotherapy has not surprisingly come to the fore as a means to treat cancer $[1,2]$. To stimulate anti-tumoral adaptive immunity, novel vaccine strategies are required. Attenuation and reverse genetics have allowed the development of viral vectors to deliver tumor-associated antigens (TAAs) [3]. Some live attenuated viral vectors can deliver transgenes directly to professional antigen-presenting cells (APCs) and dendritic cells (DCs) [4] allowing enhanced specific cytotoxic T-cells (CTLs) frequencies [5].

Attenuated measles virus (MV), a member of Morbillivirus genus in the Paramyxoviridae family, is an enveloped virus with a non-segmented negative single-stranded RNA genome which replicates exclusively in the cytoplasm [6]. Today the attenuated Schwarz/Moraten vaccine strain has a longstanding efficacy and an excellent safety record [7,8]. This vaccine induces strong cellular and humoral immune responses after one or two low-dose injections. Indeed, MV specific CD8 T-cells and antibodies persist for life [9]. The cloned MV Schwarz strain has proved to be an excellent vector allowing the incorporation of up to an additional 6 $\mathrm{kb}$, or $\sim 40 \%$ of its genome [10,11]. Proof of concept in humans has recently been demonstrated for a measles vector-based Chikungunya vaccine (MV-CHIK). The phase I clinical trial of this candidate showed that the vaccine was well tolerated and induced robust and functional antibody responses in $100 \%$ of volunteers after 2 immunizations [12]. This trial also demonstrated that pre-existing measles antibodies (anti-vector immunity) did not impair the immunogenicity of the heterologous antigen, paving the way for using recombinant MV as a vaccine vector $[13,12]$. Some TAAs like carcinoembryonic antigen (CEA) have also been efficiently expressed in this vector $[14,15]$.

Telomerase reverse transcriptase (TERT) has emerged as a near universal tumor antigen and is actively investigated as a target for cancer immunotherapy [16]. Human telomerase (hTERT) is the rate-limiting catalytic subunit of the telomerase enzyme that synthesizes telomere DNA at chromosome ends [17]. Telomerase transcriptional activation has become the most important tumor escape mechanism to circumvent telomere-dependent pathways of cell death [18]. Indeed, hTERT is overexpressed in $>85 \%$ human tumors regardless of their origin [19] and is associated with poor prognosis [20,21]. Natural anti-hTERT immune responses in some cancer patients and a pre-existing anti-hTERT repertoire in healthy volunteers show that tolerance to telomerase may be readily overcome [22]. Towards this end, we have developed a hTERT 
modified DNA plasmid (INVAC-1) vaccine candidate that elicited strong specific immune

DNA vaccines offer numerous advantages such as their capacity to readily incorporate multiple genes, their easy engineering and their stability [24]. Heterologous prime-boost strategies using a DNA prime followed by boosting with viral vectors have been shown to increase the magnitude of immune responses to HIV [25], Chikungunya virus [26], melanoma [27] or breast cancer [28]. Here, we have developed a recombinant MV vector expressing the insert of INVAC-1, which is a modified ubiquitin-hTERT fusion protein, as immunotherapeutic agent. In mouse models susceptible for MV infection, we demonstrate that immunization with a single low-dose of this construct referred to as MV-TERT, elicited strong hTERT specific cytotoxic cellular immune responses. The vector could expand primary hTERT memory responses induced by DNA priming.

\section{Materials and Methods}

\section{Construction of measles virus telomerase construct}

The pTM-MVSchw-ATU2 plasmid encodes the Ubi-hTERT insert of INVAC-1 [23] cloned into the additional transcription unit (ATU) inserted between the $\mathrm{P}$ and $\mathrm{M}$ genes of an infectious molecular clone of the Schwarz MV vaccine strain [11]. The INVAC-1 insert carries a 9 bp deletion that removes three amino acids (867VDD869) crucial to hTERT catalytic activity [29]. The first 47 residues encoding the nucleolar localization sequence (NoLS) [30] were replaced by human ubiquitin (76 residues) according to the ubiquitin-fusion approach [31] along with an HLA-A*0201 restricted influenza A virus epitope and V5 tag was added at the carboxy terminus to facilitate characterization. The entire transgene was codon optimized. The length of the insert ( $3576 \mathrm{bp}$ ) was such that the "rule of six" was respected - the number of nucleotides in a MV genome must be a multiple of 6 to allow efficient replication [32]. The transgene was synthetized by GeneCust (Luxembourg) and subcloned into the BsiWI/BssHII restriction sites of the pTM-MVSchw-ATU2 vector generating a plasmid designated pTM-MV-TERT.

\section{Rescue of recombinant MV-TERT and MVSchw from cloned cDNAs}

Recombinant MV-TERT and MVSchwarz (MVSchw) viruses were recovered using a helper cell-based rescue system [33,34]. HEK-293-T7-MV cells stably expressing both the T7-RNA polymerase and MVSchw $\mathrm{N}$ and P proteins, were co-transfected with $5 \mu \mathrm{g}$ of pTM-MV-TERT 
or pTM-MVSchw DNA and 20 ng of the pEMC-L plasmid that expresses the MV polymerase L gene. After incubation overnight at $37^{\circ} \mathrm{C}$, the cells were heat shocked at $43^{\circ} \mathrm{C}$ for 3 hours and transferred onto Vero cell monlayers and incubated at $37^{\circ} \mathrm{C}$ for two days. Individual syncytia were isolated and transferred to $35 \mathrm{~mm}$ wells with a new monolayer of Vero cells and then expanded in $25 \mathrm{~cm}^{2}$ and finally $150 \mathrm{~cm}^{2}$ flasks. Viruses were harvested when syncytia reached $90 \%$ of the culture and titers were determined by an endpoint limit dilution assay on Vero cells. Viral titers were calculated using the Kärber method and were expressed as TCID50/mL.

\section{Cell lines}

HEK293-T7-MV helper cells were cultured in DMEM (Gibco) without sodium pyruvate supplemented with $10 \%$ heat-inactivated fetal calf serum and $1 \%$ penicillin/streptomycin (Life Technologies, Saint-Aubin, France). Vero cells were maintained in DMEM without sodium pyruvate supplemented with $10 \%$ heat-inactivated fetal calf serum and $1 \%$ penicillin/streptomycin (Life Technologies, Saint-Aubin, France). For co-culture, Vero cells were seeded at $5 \times 10^{6}$ cells and grown as monolayers in $10 \mathrm{~cm}$ dishes at $37^{\circ} \mathrm{C}$ and $5 \% \mathrm{CO}_{2}$ until single syncytia formation. For amplification, $3 \times 10^{5}$ Vero cells were seeded in 12 well plates and grown to $80-90 \%$ confluence, at which time each syncytium was then transferred.

\section{Western blotting}

Vero cells were seeded at $2 \times 10^{6}$ cells and grown as monolayers in T-25 flasks and infected at a multiplicity of infection (MOI) of 0.1 . Forty-eight hours later, when syncytia reached $80-90 \%$ confluence, cells were lysed in RIPA buffer (Sigma-Aldrich, St. Louis, USA) supplemented with a protease inhibitor cocktail (Roche Diagnostic, Indianapolis, USA). Proteins were separated on Nu-PAGE ${ }^{\circledR}$ Novex 4-12\% Bis-Tris gels (Invitrogen, Carlsbad, USA) and electroblotted onto Polyvinylidene fluoride (PVDF) membranes (iBlot ${ }^{\circledR}$ device, Invitrogen, Carlsbad, USA). hTERT proteins were detected with primary mouse anti-V5 monoclonal antibody (R960-25; Invitrogen, Carlsbad, USA) and nucleoproteins with a primary mouse antiMV N monoclonal antibody (Abcys, Courtaboeuf, France). A sheep anti-mouse IgG-HRP conjugate (NA931; GE Healthcare, Buckinghamshire, UK) was used as secondary antibody. Novex ${ }^{\circledR}$ Sharp Prestained Protein Ladder (Invitrogen, Carlsbad, USA) were used to determine molecular weight. $\beta$-Actin was used as loading control. Peroxidase activity was detected on films with chemiluminescence ECL HRP substrate reagent kit (GE Healthcare, Buckinghamshire, UK). 


\section{Immunization}

MV susceptible IFNAR/CD46 and HHD/IFNAR/CD46 mice were obtained as described [3436] and were housed under specific pathogen-free conditions at the Institut Pasteur animal facility. The IFNAR/CD46 strain has been accepted by the FDA as a model of measles toxicity prior to initiation of clinical trials of engineered MV strains. Transgenic mice between 6 and 16 weeks of age were inoculated intraperitoneally (i.p.) once or twice with $10^{5}$ TCID50 of recombinant MV-TERT or MVSchw. To evaluate induction of humoral specific response, transgenic (Tg) mice were inoculated with $10^{5}$ TCID50 (D0) and $8 \times 10^{4}$ TCID50 (D28) of MVSchw and MV-TERT at 1 month intervals. For the heterologous prime-boost, priming was performed via the intradermal (i.d.) route at the base of the tail (bilateral injections) using 25 $\mu \mathrm{g}$ of INVAC-1 plasmid coding for Ubi- $\Delta$ hTERT [23] or PBS, as control. Directly after DNA vaccination, electroporation was performed using CLINIPORATOR ${ }^{\circledR} 2$ (IGEA, Carpi, Italy). The following train of pulses was applied using non-invasive plate electrodes (P-30-8G, IGEA, $0.5 \mathrm{~cm}$ apart); one high voltage pulse $(100 \mu \mathrm{s}$ duration; $1,000 \mathrm{~V} / \mathrm{cm})$ followed $1 \mathrm{~s}$ later by one low voltage pulse (400 ms duration; $140 \mathrm{~V} / \mathrm{cm})$. Twenty-one days later, mice received an i.p. boost injection with $10^{5}$ TCID50 of MV-TERT or MVSchw.

\section{ELISpot assays}

HLA-A*0201 restricted hTERT peptides have been described [37,38]. H2-K/Db and H2-IAb restricted hTERT peptides were determined in silico using the following online epitope prediction algorithms: Syfpeithi (http://www.syfpeithi.de/), Bimas (http://wwwbimas.cit.nih.gov/), NetMHCpan and SMM (http://tools.immuneepitope.org/main/). All synthetic peptides were purchased lyophilized (>90\% purity) from Proimmune (Oxford, United Kingdom) and are described in Table 1. Peptides were dissolved in sterile water at $2 \mathrm{mg} / \mathrm{mL}$ and stored at $-80^{\circ} \mathrm{C}$ or $-20^{\circ} \mathrm{C}$ prior use.

Murine IFN- $\gamma$ kits were purchased from Diaclone (Eurobio, Courtaboeuf, France) and used following the manufacturer's instructions. Ficoll-purified lymphocyte cell suspensions from peripheral blood or spleen were stimulated in triplicate at $2 \times 10^{5}$ cells/well with pools of HLAA*0201, H2-K/Db or H2-IAb restricted hTERT peptides at $5 \mu \mathrm{g} / \mathrm{mL}$, with serum free RPMI culture medium (as negative control), with MVSchw at MOI $=1$ (as immunization control) or with PMA-Ionomycin as positive control $(0.1 \mu \mathrm{M}$ and $1 \mu \mathrm{M}$ respectively). After 19 hours, spots were revealed with the biotin-conjugated detection antibody followed by streptavidin-alkaline phosphatase (AP) and 5-Bromo-4-chloro-3-indolyl phosphate/Nitro blue tetrazolium chloride 
(BCIP/NBT) substrate solution. Spots were counted using the Immunospot ELISpot counter and software (Cellular Technology Limited, Bonn, Germany).

\section{Bioluminescence imaging}

Transgenic mice were immunized with $10^{5}$ TCID50 of recombinant MV-Luc expressing the luciferase gene [39] or MVSchw as control. Immunized mice received i.p. $150 \mathrm{mg} / \mathrm{kg}$ body weight of a D-luciferin potassium salt solution at $30 \mathrm{mg} / \mathrm{mL}$ (Perkin Elmer Life Sciences, Villebon-sur-Yvette, France). Five minutes later, they were anesthetized with 2-3\% isoflurane (Attane Isoflurane, JD Medical Dist. Co., Inc., Phoenix, AZ, USA) delivered in 100\% oxygen at a flow rate of 0.8 liter/min and imaged using an IVIS Lumina while the results were analyzed using Living Image software (both Caliper Life Sciences, Hopkinton, MA, USA). Luciferin signals were followed during 8 days until the mice were euthanized using region of interest (ROI) drawing. Bioluminescence signal was expressed as average radiance ( $\mathrm{ph} / \mathrm{sec} / \mathrm{cm}^{2} / \mathrm{sr}$ ).

\section{In vivo cytotoxicity assay}

The capacity of CD8 CTLs to kill peptide loaded target cells in vivo was assessed as described [40]. Briefly, splenocytes from naive IFNAR/CD46 mice were split in three and labeled with high $(5 \mu \mathrm{M})$, medium $(1 \mu \mathrm{M})$ or low $(0.2 \mu \mathrm{M})$ concentrations of CFSE (Vybrant CFDA-SE cell-tracer kit; Life Technologies, Saint-Aubin, France). Subsequently, CFSE ${ }^{\text {high }}$-labeled cells were pulsed with the immunodominant hTERT p660 peptide and CFSE ${ }^{\text {medium}}$-labeled cells were pulsed with the subdominant p1021 hTERT peptide for 1.5 hours whereas CFSE ${ }^{\text {low }}$-labeled cells were left unpulsed. Cells were mixed in a 1:1:1 ratio and $6.8 \times 10^{6}$ cells in $50 \mu \mathrm{L}$ of PBS were intravenously injected at day 7 into mice previously vaccinated with MV-TERT, MVSchw or PBS. Fifteen hours later, single-cell suspensions from immunized mice spleen were analyzed by MACSQuant ${ }^{\circledR}$ flow cytometer (Miltenyi, Germany). The percentage of specific killing was determined as follows:

$\left[1-\left[\right.\right.$ mean $\left.\left.\left(\% \mathrm{CFSE}^{\text {low }} / \mathrm{CFSE}^{\text {high or medium }}\right)_{\mathrm{CONTROL}} /\left(\% \mathrm{CFSE}^{\text {low }} / \mathrm{CFSE}^{\text {high or medium }}\right)_{\text {IMMUNIZED }}\right]\right] \times$ 100.

\section{ELISA for humoral responses}

Sera collected before immunization (D0) and 1 month after each vaccination (D28 and D49) were heat inactivated. MV-specific Ig antibodies were measured by using commercial ELISA kit (Trinity Biotech, USA). Briefly, plates were coated overnight with $50 \mathrm{ng}$ of MV antigens and D28 and D49 sera were serially diluted to determine the end point positive limit dilution. 
An anti-mouse antibody-HRP conjugate (Amersham) was used as secondary antibody with

\section{Statistical analyses}

GraphPad Prism 6.0 software was used for data handling, analysis and graphic representations. Data are represented as the mean \pm standard deviation. Statistical analyses were performed using a two-tailed Mann Whitney test. Significance was set at $\mathrm{p}$-value $\leq 0.05$.

\section{Results}

\section{Efficient expression of hTERT from recombinant MV vector}

The Ubi- $\Delta$ hTERT-Flu-V5 transgene was cloned into pTM-MVSchw-ATU2 (Fig. 1a). Expression of hTERT fusion protein was assessed by Western blot using MV-TERT infected- 
cell lysates with V5-specific antibodies (Fig. 1b). The full length Ubi- $\Delta$ hTERT-Flu-V5 fusion protein was identified at the predicted size of $130.9 \mathrm{kDa}$. The strongest band at $122.5 \mathrm{kDa}$ corresponds to processing and removal of the ubiquitin moiety from the fusion protein as previously reported for INVAC-1 [23]. There is an additional, weaker N-terminal degradation product around $100 \mathrm{kDa}$, which is not surprising given that ubiquitin was added to facilitate degradation. Both MV-TERT and MVSchw constructs expressed the $57.7 \mathrm{kDa} \mathrm{MV}$ nucleoprotein to comparable levels (Fig. 1b) indicating the stability of MV-TERT construct.

\section{Immunization elicited high frequencies of hTERT specific CD8 T-cells}

The immunogenicity of MV-TERT recombinant vector was assessed using MV susceptible IFNAR/CD46 and HHD/IFNAR/CD46 mice. Mice were immunized i.p. with $10^{5}$ TCID50 of each virus. Both hTERT and MV specific T-cell responses were monitored in splenocytes collected at 7 or 14 days post-immunization using an IFN- $\gamma$ ELISpot assay with specific hTERT peptides for ex vivo re-stimulation and MVSchw virus for control stimulation (Fig. 2). To assess MV-TERT immunogenicity in HHD/IFNAR/CD46 mice, splenocytes were stimulated in vitro with a mix of HLA-A*0201 restricted hTERT peptides for a week. As expected, strong hTERT specific CD8 T-cell responses were observed in IFNAR/CD46 or HHD/IFNAR/CD46 MV-TERT immunized mice at 7 and 14 days after the last immunization compared to the MVSchw controls $(\mathrm{p}<0.01)$ (Figs. $2 \mathrm{a}$ and $\mathrm{b})$. Similarly, hTERT specific CD4 T-cells were detected in MV-TERT immunized mice for all H2-restricted hTERT peptides tested, as compared to the MVSchw controls (Fig. 2c). Interestingly, the strength of MV specific T-cell responses was comparable for the two viruses indicating that the hTERT transgene did not impact the existing immunogenicity of MV (Figs. 2a and c).

Specific T-cells frequencies were highest on day 7 for control MVSchw and MV-TERT, while their frequencies decreased slightly by day 14 (i.e. Fig. 2a) indicating that both MVSchw and MV-TERT replicate efficiently and probably cleared after 6-7 days post-immunization due to the ramping up of immune responses. To corroborate this interpretation, vector replication and clearance were measured in vivo using a recombinant MV-luciferase vector (pTM2-MV/Luc [39]) and monitored by bioluminescence imaging (Fig. 2d). Luciferase activity was detected between 1-6 days post-infection (maximum average radiance at D3 $=2.01 \times 10^{5} \mathrm{p} / \mathrm{s} / \mathrm{cm}^{2} / \mathrm{sr}$; Fig. $2 \mathrm{~d}$ left) and had virtually disappeared by D8 when sacrificed. Even dissection of the animals failed to identify more luciferin activity at day 8 (D8) (Fig. 2d far right). 


\section{MV-TERT specific CD8 T-cells are cytolytic in vivo}

To demonstrate that recombinant MV-TERT induces cytolytic hTERT specific CD8 T-cells, an in vivo killing assay was performed in IFNAR/CD46 mice using, CFSE-labeled and hTERT peptide pulsed (p660 and p1021) splenocytes or unpulsed splenocytes as target cells. Flow cytometry showed a strong decrease of p660 and p1021 pulsed CFSE cells in MV-TERT immunized mice compared to MVSchw controls illustrating that specific target cells were lysed when they were adoptively transferred into congenic recipient MV-TERT immunized mice (Fig. 3a). Human TERT specific CTLs from MV-TERT immunized mice killed 50\% of p660 pulsed cells and $\sim 14 \%$ of p1021 pulsed cells (Fig. 3 b).

\section{MV-TERT did not elicit hTERT antibodies}

As MV infection is cytolytic, we wondered whether MV-TERT vaccination might induce hTERT antibodies. To explore this, IFNAR/CD46 and HHD/IFNAR/CD46 mice were immunized twice at a one month interval. MV and TERT specific ELISAs were performed using sera collected at D0, D28 and D49 (Fig. 4). The TERT ELISA plates were coated with a recombinant protein, residues 165-348, as target. As positive or negative results were determined with $\mathrm{R}=\mathrm{OD}$ values/cut off point and according the control (QC) ratio (IFNAR/CD46: $\quad \mathrm{R} \quad$ QC $\quad$ high=7.27-7.67; $\quad \mathrm{R}$ QC low=1.46-1.50; $\quad$ cut-off $=0.252$. HHD/IFNAR/CD46: R QC high=8.30-8.99; R QC low=1.43-1.44; cut-off = 0.279), no antihTERT antibodies were detected in both mouse strains after one or two immunizations (Figs. 4a and b). By contrast, for both mouse strains, anti-MV antibodies were detected after one MV-TERT immunization (D28: IFNAR/CD46 $=81,000 ; \mathrm{HHD} / \mathrm{IFNAR} / \mathrm{CD} 46=6,800$ ) followed by a 3-7-fold increase after the second immunization (D49: IFNAR/CD46 = 280,000; HHD/IFNAR/CD46 = 52,000) (Figs. $4 \mathrm{c}$ and d). These titers did not differ significantly to those generated by the control MVSchw virus (Figs. $4 \mathrm{a}$ and $\mathrm{b}$ ). These findings confirm that the TERT transgene did not impact MV humoral immunogenicity.

\section{Heterologous prime-boost elicited enhanced and multifunctional hTERT responses}

Heterologous prime-boost vaccination can enhance vaccine specific immune responses in infectious diseases and cancer [41]. To test this strategy, we vaccinated a group of ten IFNAR/CD46 mice with INVAC-1 DNA and boosted six with MV-TERT and four with MVSchw 21 days later (Fig. 5). TERT specific CD8 T-cells were monitored by an IFN- $\gamma$ ELISpot assay in PBMCs over time (Fig. 5a) and in splenocytes at each end-point (Fig. 5b). Priming with a single shot of INVAC-1 resulted in weak to no hTERT specific CD8 T-cell 
responses at 14 days post-immunization; only $2 / 10$ mice developed weak responses in blood (Fig. 5a). This is not surprising given that DNA priming is known to be poor in IFNAR KO mice [42,43]. Animals were boosted with MV constructs 21 days post DNA prime immunization. One week later strong hTERT specific CD8 T-cell responses were detected in the PBMCs of MV-TERT boosted group in comparison of MVSchw boosted mice (Fig. 5a, mean \#spots: 118.5; $n=6$ ). In the spleen, significant numbers of hTERT specific CD8 T-cells were detected after boosting with MV-TERT compared to controls (Fig. 5b, mean \#spots: 453.7 (DNA+MV-TERT; $n=6)$ versus $0.7(D N A ; n=6)$ or 22.5 (DNA+MVSchw; $n=4) ; p=0.0022$ and 0.0095) and compared to only one MV-TERT injection (Fig. 5b, mean \#spots: 453.7 (DNA+MV-TERT; $n=6$ ) versus 160.4 (MV-TERT; $n=13$ ); $\mathrm{p}=0.0047$ ). A significant difference in MV specific T-cell responses was observed between a MV-TERT prime and DNA+MV-TERT boost as expected from the immunization strategy. In keeping with this, no difference in MV specific T-cell responses between DNA+MVSchw or DNA+MV-TERT boost were found (Fig. 5b).

In order to demonstrate the functionality of the hTERT and MV specific T-cells after heterologous prime-boost vaccination, secreted cytokines were assessed using CBA with overnight stimulation supernatant. Significant concentrations of IL-6, IFN- $\gamma$ and TNF were secreted by hTERT specific CD8 T-cells induced by MV-TERT compared to MVSchw, (Fig. 5c). MV specific T-cells secreted the same cytokine, IL-2, IL-6, IL-10, IFN- $\gamma$ and TNF, whether boosted by MV-TERT or MVSchw (Fig. 5d). Taken together, these results demonstrated that priming with INVAC-1 DNA and boosting by MV-TERT elicit a powerful TERT specific Th1 response while a more mixed polarized response was induced to MV.

\section{Discussion}

With a heterologous prime-boost strategy in mind, we developed a recombinant MV vaccine vector expressing the modified ubiquitin-hTERT fusion protein, to increase the magnitude of hTERT specific immune responses. This choice reflects promising vector properties of the MV vaccine that is characterized by long standing safety and efficacy with immunity persisting for up to 25-30 years $[8,14]$. As MV targets the human CD46 receptor, it allows hTERT antigen production directly within macrophages, DCs and lymphocytes [8]. The recombinant MVvectored Ubi- $\triangle$ hTERT-Flu-V5 fusion protein was efficiently expressed and presented a similar degradation profile compared to native INVAC-1 reflecting ubiquitin-fusion [44]. As the construct carried a deletion in the catalytic site resulting in complete activation, there was no 
risk of cellular transformation. This is further compounded by the fact that MV infection is lytic Bioluminescence imaging data demonstrated efficient vector replication two days after immunization and its partial clearance six days later by the ramping up of MV specific immune response in Tg IFNAR/CD46 mice, confirming the transitory nature of MV transgene delivery in vivo.

The MV-TERT construct induced high levels of MV and hTERT specific CD8 and CD4 T-cells seven and fourteen days after a low dose $\left(10^{4}-10^{5}\right.$ TCID50) immunization. The hTERT specific CD8 T-cells were able to recognize and lyse specific target cells in vivo, which is crucial to the induction of antitumor immunity. An important consideration in this study for the recombinant MV kinetics is the choice of IFNAR KO mice model that allows powerful and rapid viral replication in the absence of IFN type I context and subsequently the induction of specific immune response within seven days [45]. Similar experiments using a recombinant wild-type MV-EGFP in macaques have demonstrated that the levels of MV-infected lymphocytes increase exponentially during the first 7-9 days due to viral replication but decrease rapidly during the subsequent week with the appearance of MV specific T-cells [46].

The primary goal of the present study was to test a heterologous INVAC-1 DNA prime - MVTERT boost strategy to expand hTERT specific immune responses. As expected for IFNAR $\mathrm{KO}$ mice, the present findings reiterate the observation that DNA vaccination is weak in this background $[42,43]$ compared to our previous work with INVAC-1 DNA on syngeneic or HLA Tg mice only [23]. It also should be noted that hTERT specific CD8 T-cell response induced by heterologous prime-boost was 2-3 fold higher than the response after one MV-TERT immunization (Fig. 5b vs. Fig. 2a). This suggests that INVAC-1 DNA vaccination in IFNAR/CD46 mice induced hTERT specific CD8 T-cell repertoires but did not enable their expansion, in contrast to MV-TERT immunization. Indeed, low dose of DNA and its adjuvant properties are generally efficient to initiate and expand primary immune responses but they are less relevant to raise the level of secondary memory responses in contrast of live attenuated viral vectors [47].

This, along with our results, shows that INVAC-1 DNA prime and MV-TERT boost elicit hTERT specific and effective CD8 T-cells with Th1 polarization in a mixed response to MV [48]. In addition, differences in MV specific T-cell responses observed between a MV-TERT 
prime and DNA+MV-TERT prime-boost but not observed between MVSchw or MV-TERT

\section{Author contributions}

Simon Wain-Hobson, Frédéric Tangy and Pierre Langlade-Demoyen conceived the project. They also shared their knowledge and experience to help Elodie Pliquet with the experimental program design.

Elodie Pliquet performed and analyzed the experiments under the supervision of Christelle Liard and Thierry Huet. Elodie Pliquet and Claude Ruffie carried out mice experiments. Valérie Najburg and Chantal Combredet constructed the recombinant measles-telomerase virus. Marie Escande, Jessie Thalmensi, Thomas Bestetti and Marion Julithe provided technical help. Elodie Pliquet analysed all the data and wrote the manuscript together with Simon WainHobson and Frédéric Tangy. All authors viewed and approved the final version of the manuscript.

\section{Acknowledgments}

The authors would like to thank Ludovic Bourré, Anne-Sophie Pailhes-Jimenez, Emanuèle Bourges, Rahima Youssi and Pascal Clayette for experimental and editorial help, and the staff of the Institut Pasteur's animal facilities and imaging platform.

\section{Funding}

We would like to thank Shannon A. Fairbanks and Bernardo Fort Brescia for their unswerving support. Elodie Pliquet was supported by an industrial $\mathrm{PhD}$ fellowship from the French National Association of Research and Technology (ANRT).

\section{Compliance with ethical standards}

Conflict of interest

The authors declare that they have no conflict of interest.

\section{Ethical approval and ethical standards}

All protocols have been submitted and approved by the Pasteur Institute office of laboratory animal care CETEA N ${ }^{\circ} 89$ under the references 2013-0026 on February 01 ${ }^{\text {st }}, 2013$ and 20140061 on October $07^{\text {th }}, 2015$ and by French Committee for Hygiene, Safety and Working 
Conditions (CHSCT) under the reference 07.157 on April $10^{\text {th, } 2007}$ and 16.0013 on January $8^{\text {th }}, 2016$.

All in vivo experiments were conducted in strict accordance with good animal practice and complied with local animal experimentation and ethics committee guidelines of the Pasteur Institute (agreement $N^{\circ} 75-15-01$ delivered on the $06^{\text {th }}$ September 2013 and $N^{\circ} A 75-15-01-1$ on $18^{\text {th }}$ August 2014) and Directive 2010/63/EU on the harmonization of laws, regulations and administrative provisions relating to the protection of animals.

\begin{abstract}
Animal source
IFNAR/CD46 (IFN- $\alpha / \beta \mathrm{R}^{-/-} \mathrm{CD} 46^{+/-}$) mouse strain used for immunization experiments was generated by Frédéric Tangy's team by cross-breeding and backcross between FVB/CD46 ${ }^{+/-}$ mice (gift from F. Grosveld, Erasmus University, Rotterdam, The Netherlands) and 129sv IFN$\alpha / \beta \mathrm{R}^{-/-}$mice which lack the type I IFN receptor (gift from M. Aguet, Swiss Institute for Experimental Cancer Research, Epalinges, Switzerland).
\end{abstract}

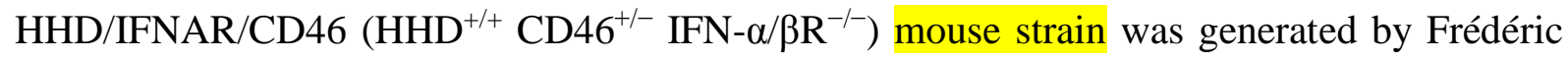
Tangy's team by cross-breeding and backcross between HHD mice (human $\beta 2 \mathrm{~m}-$ HLA-A2.1 $\alpha 1 \alpha 2-\mathrm{H}-2 \mathrm{D}^{\mathrm{b}} \alpha 3$-transmembrane and $\mathrm{H}-2 \mathrm{Db}^{-/-} \beta 2 \mathrm{mb}^{-/-}$double knockout; mice generated at Pasteur Institute by François Lemonnier) and IFNAR/CD46 mice.

\title{
Cell line authentication
}

HEK-293-T7-MV cell line was produced, provided and patented by Frédéric Tangy and the Institut Pasteur. Vero cells were provided by the American Type Culture Collection (ATCC ${ }^{\circledR}$ ) under reference number CCL-81 ${ }^{\mathrm{TM}}$.

\section{Figure legends}

Fig. 1 Recombinant MV-TERT construction and expression

(a) Schematic maps of the pTM-MV-TERT plasmid. The MV orfs are: N, nucleoprotein; P, phosphoprotein including $\mathrm{C}$ and $\mathrm{V}$ proteins; $\mathrm{M}$, matrix; $\mathrm{F}$, fusion; $\mathrm{H}$, hemagglutinin; $\mathrm{L}$, polymerase. T7, T7 RNA polymerase promoter; hh, hammerhead ribozyme; h $\partial \mathrm{v}$, hepatitis delta virus ribozyme; T7t, T7 RNA polymerase terminator. (b) Western blot of hTERT transgene and MV nucleoproteins. $\beta$-Actin served as loading control.

\section{Fig. 2 Induction of hTERT specific CD8 and CD4 T-cells}


(a) MV and hTERT CD8 specific T-cell responses were evaluated seven or fourteen days postusing a mix of hTERT specific peptides restricted to HLA-A*0201 on HHD/IFNAR/CD46 mice seven days post-immunization (MVSchw $n=4$; MV-TERT $n=6$ ) after one week of in vitro stimulation with the same peptides. (c) Seven days post-immunization ( $\mathrm{n}=3$ mice/group), MV, hTERT CD8 and CD4 specific T-cell responses were evaluated using MV, pool of H2-K/Db restricted hTERT peptides or individual H2-IAb restricted hTERT peptides. (a, b, c) MV stimulation was used as immunization control. Data are represented as mean \pm SD. Mann Whitney non-parametric test against mice control (MVSchw), **p<0.01. (d) Kinetics of recombinant MV-Luc replication cycle on IFNAR/CD46 mice (MVSchw n=1; MV-TERT n=5, data shown $2 / 5$ mice).

\section{Fig. 3 MV-TERT induces hTERT specific cytotoxic T-cells in vivo}

(a) The disappearance of naive peptide-pulsed-splenocyte in spleens of IFNAR/CD46 mice immunized once with PBS, MVSchw or MV-TERT was analyzed by flow cytometry (mean data shown per group). Gating was based on FSC/SSC parameters with doublet discrimination. Viable single stained cells were analyzed with FITC channel corresponding to CFSE fluorescence. (b) Percent killing for p660 (black bars) and p1021 (hatched bars) was calculated using cytometry data and was presented as mean \pm SD (MVSchw $n=3 ;$ MV_TERT $n=5)$. Mann Whitney non-parametric test against mice control (MVSchw), ${ }^{*} \mathrm{p}<0.05$.

\section{Fig. 4 Antibody responses following MV-TERT immunization}

(a, b) Detection of anti-hTERT antibody after MV-TERT prime-boost immunization (before immunization (D0) and one month after last immunization (D28 and D49)). Results are expressed as mean ratio $(\mathrm{R}) \pm \mathrm{SD}$. Mann Whitney non-parametric test against MVSchw control was performed for each day. (c, d) Anti-MV antibody titers detected according the same schedule. Results are expressed as mean values \pm SD determined in serial dilutions of sera. Mann Whitney non-parametric test against MVSchw control was performed. (a, c) Data on IFNAR/CD46 mice (MVSchw $\mathrm{n}=3$; MV-TERT $\mathrm{n}=5$ ) and $(\mathbf{b}, \mathbf{d})$ on HHD/IFNAR/CD46 (MVSchw n=4; MV-TERT n=6). 
Fig. 5 Heterologous DNA prime / MV-TERT boost induced multiple patterns of T-cell responses

(a) Individual hTERT CD8 specific T-cell response at days 0, 7, 14 and 21 post-priming and at day 7 post-boost (D28) on PBMCs stimulated with pool of hTERT specific peptides restricted to $\mathrm{H} 2-\mathrm{K} / \mathrm{Db}$. Black arrows indicate vaccination. (b) At day 28, MV specific T-cells and hTERT specific CD8 T-cells were detected on ficoll-purified splenocytes with MV or pool of hTERT specific peptides restricted to H2-K/Db. Data for prime with PBS ( $n=4)$, INVAC-1 (n=6) or MV-TERT ( 3 experiments, $n=13$ ) (hatched bars) and prime-boost with INVAC-1 + MVSchw $(n=4)$ or MV-TERT $(n=6)$ (grey bars) are represented as mean \pm SD. MV specific T-cell stimulation was used as immunization control. Mann Whitney non-parametric test between INVAC-1+MV-TERT and INVAC-1 DNA or MV-TERT alone, **p<0.01. (c) At day 28, concentration of different cytokines secreted by hTERT specific CD8 T-cells and (d) by MV specific T-cells was evaluated using CBA assay. Cytokine concentrations in $\mathrm{pg} / \mathrm{mL}$ are represented as mean \pm SD. Mann Whitney non-parametric test against mice control (MVSchw), $* \mathrm{p}<0.05 ; * * \mathrm{p}<0.01$. 


\section{References}

1. Eggermont AMM, Kroemer G, Zitvogel L (2013) Immunotherapy and the concept of a clinical cure. Eur J Cancer 49 (14):2965-2967.https://doi.org/10.1016/j.ejca.2013.06.019

2. Bluestone JA, Small EJ (2012) The Future of Cancer Treatment: Will It Include Immunotherapy? Cancer Cell 22 (1):7-8.https://doi.org/10.1016/j.ccr.2012.06.009

3. Draper SJ, Heeney JL (2010) Viruses as vaccine vectors for infectious diseases and cancer. Nat Rev Microbiol 8 (1):62-73.https://doi.org/10.1038/nrmicro2240

4. Bonnet MC, Tartaglia J, Verdier F, Kourilsky P, Lindberg A, Klein M, Moingeon P (2000) Recombinant viruses as a tool for therapeutic vaccination against human cancers. Immunol Lett 74 (1):11-25.https://doi.org/10.1016/S0165-2478(00)00244-3

5. Larocca C, Schlom J (2011) Viral Vector -based Therapeutic Cancer Vaccines. Cancer J 17 (5):359-371.https://doi.org/10.1097/PPO.0b013e3182325e63

6. Moss WJ, Griffin DE (2012) Measles. Lancet 379 (9811):153-164. https://doi.org/10.1016/S0140-6736(10)62352-5

7. Hilleman MR (2001) Current overview of the pathogenesis and prophylaxis of measles with focus on practical implications. Vaccine 20 (5-6):651665.https://doi.org/10.1016/S0264-410X(01)00384-X

8. Guillerme J-B, Gregoire M, Tangy F, Fonteneau J-F (2013) Antitumor Virotherapy by Attenuated Measles Virus (MV). Biology 2 (2):587.https://doi.org/10.3390/biology2020587

9. Amanna IJ, Carlson NE, Slifka MK (2007) Duration of humoral immunity to common viral and vaccine antigens. N Engl J Med 357 (19):1903-

1915.https://doi.org/10.1056/NEJMoa066092

10. Zuniga A, Wang Z, Liniger M, Hangartner L, Caballero M, Pavlovic J, Wild P, Viret JF, Glueck R, Billeter MA, Naim HY (2007) Attenuated Measles Virus as a Vaccine Vector. Vaccine 25 (16):2974-2983.https://doi.org/10.1016/j.vaccine.2007.01.064

11. Brandler S, Tangy F (2008) Recombinant vector derived from live attenuated measles virus: potential for flavivirus vaccines. Comp Immunol Microbiol Infect Dis 31 (2-3):271291.https://doi.org/10.1016/j.cimid.2007.07.012

12. Ramsauer K, Schwameis M, Firbas C, Mullner M, Putnak RJ, Thomas SJ, Despres P, Tauber E, Jilma B, Tangy F (2015) Immunogenicity, safety, and tolerability of a recombinant measles-virus-based chikungunya vaccine: a randomised, double-blind, placebo-controlled, active-comparator, first-in-man trial. Lancet Infect Dis 15 (5):519-

527.https://doi.org/10.1016/S1473-3099(15)70043-5

13. Knuchel MC, Marty RR, Morin TN, Ilter O, Zuniga A, Naim HY (2013) Relevance of a pre-existing measles immunity prior immunization with a recombinant measles virus vector. Hum Vaccin Immunother 9 (3):599-606.https://doi.org/10.4161/hv.23241 
14. Russell SJ, Peng KW (2009) Measles virus for cancer therapy. Curr Top Microbiol Immunol 330:213-241

15. Msaouel P, Iankov ID, Allen C, Morris JC, von Messling V, Cattaneo R, Koutsilieris M, Russell SJ, Galanis E (2009) Engineered measles virus as a novel oncolytic therapy against prostate cancer. Prostate 69 (1):82-91.https://doi.org/10.1002/pros.20857

16. Zanetti M (2017) A second chance for telomerase reverse transcriptase in anticancer immunotherapy. Nat Rev Clin Oncol 14 (2):115-

128.https://doi.org/10.1038/nrclinonc.2016.67

17. Collins K, Mitchell JR (2002) Telomerase in the human organism. Oncogene 21 (4):564579.https://doi.org/10.1038/sj.onc.1205083

18. Low KC, Tergaonkar V (2013) Telomerase: central regulator of all of the hallmarks of cancer. Trends Biochem Sci 38 (9):426-434.https://doi.org/10.1016/j.tibs.2013.07.001

19. Shay JW, Bacchetti S (1997) A survey of telomerase activity in human cancer. Eur J Cancer 33 (5):787-791.https://doi.org/10.1016/S0959-8049(97)00062-2

20. Zhu CQ, Cutz JC, Liu N, Lau D, Shepherd FA, Squire JA, Tsao MS (2006) Amplification of telomerase (hTERT) gene is a poor prognostic marker in non-small-cell lung cancer. Brit $\mathrm{J}$ Cancer 94 (10):1452-1459.https://doi.org/10.1038/sj.bjc.6603110

21. Lü M-H, Deng J-Q, Cao Y-L, Fang D-C, Zhang YAO, Yang S-M (2012) Prognostic role of telomerase activity in gastric adenocarcinoma: A meta-analysis. Exp Ther Med 3 (4):728734.https://doi.org/10.3892/etm.2012.471

22. Karanikas V, Zamanakou M, Soukou F, Kerenidi T, Gourgoulianis KI, Germenis AE (2010) Naturally occurring tumor-specific CD8+ T-cell precursors in individuals with and without cancer. Immunol Cell Biol 88 (5):575-585.https://doi.org/10.1038/icb.2010.8

23. Thalmensi J, Pliquet E, Liard C, Escande M, Bestetti T, Julithe M, Kostrzak A, PailhesJimenez A-S, Bourges E, Loustau M, Caumartin J, Lachgar A, Huet T, Wain-Hobson S, Langlade-Demoyen P (2016) Anticancer DNA vaccine based on human telomerase reverse transcriptase generates a strong and specific T cell immune response. Oncoimmunology 5 (3):e1083670.https://doi.org/10.1080/2162402X.2015.1083670

24. Rice J, Ottensmeier CH, Stevenson FK (2008) DNA vaccines: precision tools for activating effective immunity against cancer. Nat Rev Cancer 8 (2):108120.https://doi.org/10.1038/nrc2326

25. Brown SA, Surman SL, Sealy R, Jones BG, Slobod KS, Branum K, Lockey TD, Howlett N, Freiden P, Flynn P, Hurwitz JL (2010) Heterologous Prime-Boost HIV-1 Vaccination Regimens in Pre-Clinical and Clinical Trials. Viruses 2 (2):435-

467.https://doi.org/10.3390/v2020435

26. Hallengärd D, Lum F-M, Kümmerer BM, Lulla A, Lulla V, García-Arriaza J, Fazakerley JK, Roques P, Le Grand R, Merits A, Ng LFP, Esteban M, Liljeström P (2014) Prime-Boost 
Immunization Strategies against Chikungunya Virus. J Virol 88 (22):1333313343.https://doi.org/10.1128/JVI.01926-14

27. Smith CL, Dunbar PR, Mirza F, Palmowski MJ, Shepherd D, Gilbert SC, Coulie P, Schneider J, Hoffman E, Hawkins R, Harris AL, Cerundolo V (2005) Recombinant modified vaccinia Ankara primes functionally activated CTL specific for a melanoma tumor antigen epitope in melanoma patients with a high risk of disease recurrence. Int J Cancer 113 (2):259266.https://doi.org/10.1002/ijc.20569

28. Kim SB, Ahn JH, Kim J, Jung KH (2015) A phase 1 study of a heterologous prime-boost vaccination involving a truncated HER2 sequence in patients with HER2-expressing breast cancer. Mol Ther Methods Clin Dev 2:15031.https://doi.org/10.1038/mtm.2015.31

29. Drosopoulos WC, Prasad VR (2007) The active site residue Valine 867 in human telomerase reverse transcriptase influences nucleotide incorporation and fidelity. Nucleic Acids Res 35 (4):1155-1168.https://doi.org/10.1093/nar/gkm002

30. Yang Y, Chen Y, Zhang C, Huang H, Weissman SM (2002) Nucleolar localization of hTERT protein is associated with telomerase function. Exp Cell Res 277 (2):201209.https://doi.org/10.1006/excr.2002.5541

31. Bachmair A, Finley D, Varshavsky A (1986) In vivo half-life of a protein is a function of its amino-terminal residue. Science 234 (4773):179-

186.https://doi.org/10.1126/science.3018930

32. Bankamp B, Takeda M, Zhang Y, Xu W, Rota PA (2011) Genetic Characterization of Measles Vaccine Strains. J Infect Dis 204 (suppl 1):S533-

S548.https://doi.org/10.1093/infdis/jir097

33. Radecke F, Spielhofer P, Schneider H, Kaelin K, Huber M, Dotsch C, Christiansen G, Billeter MA (1995) Rescue of measles viruses from cloned DNA. The EMBO journal 14 (23):5773-5784

34. Combredet C, Labrousse V, Mollet L, Lorin C, Delebecque F, Hurtrel B, McClure H, Feinberg MB, Brahic M, Tangy F (2003) A molecularly cloned Schwarz strain of measles virus vaccine induces strong immune responses in macaques and transgenic mice. J Virol 77 (21):11546-11554.https://doi.org/10.1128/JVI.77.21.11546-11554.2003

35. Lorin C, Delebecque F, Labrousse V, Da Silva L, Lemonnier F, Brahic M, Tangy F (2005) A recombinant live attenuated measles vaccine vector primes effective HLA-A0201restricted cytotoxic T lymphocytes and broadly neutralizing antibodies against HIV-1 conserved epitopes. Vaccine 23 (36):4463-4472.https://doi.org/10.1016/j.vaccine.2005.04.024

36. Pascolo S, Bervas N, Ure JM, Smith AG, Lemonnier FA, Perarnau B (1997) HLA-A2.1restricted education and cytolytic activity of CD8(+) T lymphocytes from beta2 microglobulin (beta2m) HLA-A2.1 monochain transgenic $\mathrm{H}-2 \mathrm{Db}$ beta2m double knockout mice. J Exp Med 185 (12):2043-2051.https://doi.org/10.1084/jem.185.12.2043

37. Hernandez J, Garcia-Pons F, Lone YC, Firat H, Schmidt JD, Langlade-Demoyen P, Zanetti M (2002) Identification of a human telomerase reverse transcriptase peptide of low 
affinity for HLA A2.1 that induces cytotoxic T lymphocytes and mediates lysis of tumor cells. Proc Natl Acad Sci USA 99 (19):12275-12280.https://doi.org/10.1073/pnas.182418399

38. Dosset M, Godet Y, Vauchy C, Beziaud L, Lone YC, Sedlik C, Liard C, Levionnois E, Clerc B, Sandoval F, Daguindau E, Wain-Hobson S, Tartour E, Langlade-Demoyen P, Borg C, Adotevi O (2012) Universal cancer peptide-based therapeutic vaccine breaks tolerance against telomerase and eradicates established tumor. Clinical cancer research : an official journal of the American Association for Cancer Research 18 (22):62846295.https://doi.org/10.1158/1078-0432.CCR-12-0896

39. Komarova AV, Combredet C, Meyniel-Schicklin L, Chapelle M, Caignard G, Camadro JM, Lotteau V, Vidalain PO, Tangy F (2011) Proteomic analysis of virus-host interactions in an infectious context using recombinant viruses. Mol Cell Proteomics 10 (12):M110 007443.https://doi.org/10.1074/mcp.M110.007443

40. Durward M, Harms J, Splitter G (2010) Antigen specific killing assay using CFSE labeled target cells. Journal of visualized experiments : JoVE (45).https://doi.org/10.3791/2250

41. Lu S (2009) Heterologous prime-boost vaccination. Current opinion in immunology 21 (3):346-351.https://doi.org/10.1016/i.coi.2009.05.016

42. Ishii KJ, Kawagoe T, Koyama S, Matsui K, Kumar H, Kawai T, Uematsu S, Takeuchi O, Takeshita F, Coban C, Akira S (2008) TANK-binding kinase-1 delineates innate and adaptive immune responses to DNA vaccines. Nature 451 (7179):725-

729.https://doi.org/10.1038/nature06537

43. Coban C, Kobiyama K, Aoshi T, Takeshita F, Horii T, Akira S, Ishii KJ (2011) Novel strategies to improve DNA vaccine immunogenicity. Curr Gene Ther 11 (6):479484.https://doi.org/10.2174/156652311798192815

44. Tasaki T, Sriram SM, Park KS, Kwon YT (2012) The N-end rule pathway. Annu Rev Biochem 81:261-289.https://doi.org/10.1146/annurev-biochem-051710-093308

45. Mrkic B, Pavlovic J, Rulicke T, Volpe P, Buchholz CJ, Hourcade D, Atkinson JP, Aguzzi A, Cattaneo R (1998) Measles virus spread and pathogenesis in genetically modified mice. J Virol 72 (9):7420-7427

46. Ludlow M, de Vries RD, Lemon K, McQuaid S, Millar E, van Amerongen G, Yuksel S, Verburgh RJ, Osterhaus AD, de Swart RL, Duprex WP (2013) Infection of lymphoid tissues in the macaque upper respiratory tract contributes to the emergence of transmissible measles virus. J Gen Virol 94 (Pt 9):1933-1944.https://doi.org/10.1099/vir.0.054650-0

47. Woodland DL (2004) Jump-starting the immune system: prime-boosting comes of age. Trends Immunol 25 (2):98-104.https://doi.org/10.1016/j.it.2003.11.009

48. Palucka K, Ueno H, Banchereau J (2011) Recent developments in cancer vaccines. J Immunol 186 (3):1325-1331.https://doi.org/10.4049/jimmunol.0902539 
Tables

Table 1. hTERT peptides

\begin{tabular}{|c|c|c|c|c|}
\hline Peptide & Numbered to & Sequence & MHC & Mouse Strain \\
\hline 429 & \multirow{17}{*}{ Ubi- $\triangle \mathrm{hTERT}$} & HAQCPYGVL & & \multirow{4}{*}{ IFNAR/CD46 } \\
\hline 1034 & & QAYRFHACVL & $\mathrm{H} 2-\mathrm{Kb}$ & \\
\hline 660 & & RPIVNMDYV & \multirow{2}{*}{$\mathrm{H} 2-\mathrm{Db}$} & \\
\hline 1021 & & $\begin{array}{l}\text { QTVCTNIYKI } \\
\end{array}$ & & \\
\hline 85 & & VCVPWDARPPPAAPS & \multirow{8}{*}{$\mathrm{H} 2-\mathrm{IAb}$} & \multirow{8}{*}{ IFNAR/CD46 } \\
\hline 86 & & CVPWDARPPPAAPSF & & \\
\hline 87 & & $\begin{array}{l}\text { VPWDARPPPAAPSFR } \\
\end{array}$ & & \\
\hline 329 & & $\begin{array}{l}\text { GRQHHAGPPSTSRPP } \\
\end{array}$ & & \\
\hline 1080 & & MSLGAKGAAGPLPSE & & \\
\hline 1082 & & LGAKGAAGPLPSEAV & & \\
\hline 1137 & & $\begin{array}{l}\text { TLTALEAAANPALPS } \\
\end{array}$ & & \\
\hline 1138 & & LTALEAAANPALPSD & & \\
\hline $\begin{array}{l}\mathbf{5 4 0} \\
{[37]}\end{array}$ & & ILAKFLHWL & \multirow{5}{*}{$\begin{array}{c}\text { HLA- } \\
\text { A*0201 }\end{array}$} & \multirow{5}{*}{$\begin{array}{l}\text { HHD/IFNAR/ } \\
\text { CD46 }\end{array}$} \\
\hline $\begin{array}{l}\text { Y572 } \\
37]\end{array}$ & & YLFFYRKSV & & \\
\hline Y988 & & $\begin{array}{l}\text { YLQVNSLQTV } \\
\end{array}$ & & \\
\hline $\begin{array}{l}\text { UCP2.1 } \\
{[38]}\end{array}$ & & SVWSKLQSI & & \\
\hline $\begin{array}{l}\text { UCP4.1 } \\
{[38]}\end{array}$ & & SLCYSILKA & & \\
\hline
\end{tabular}

Following H2 restricted Ubi- $\triangle$ hTERT peptides have been predicted in silico; HLA-A*0201 restricted hTERT peptides were previously described $[37,38]$. Peptides were used either in ELISpot assay, CBA or in vivo cytotoxicity assay according to the strains of mouse. 


\section{FIGURE 1}

a

PTM-MV-TERT

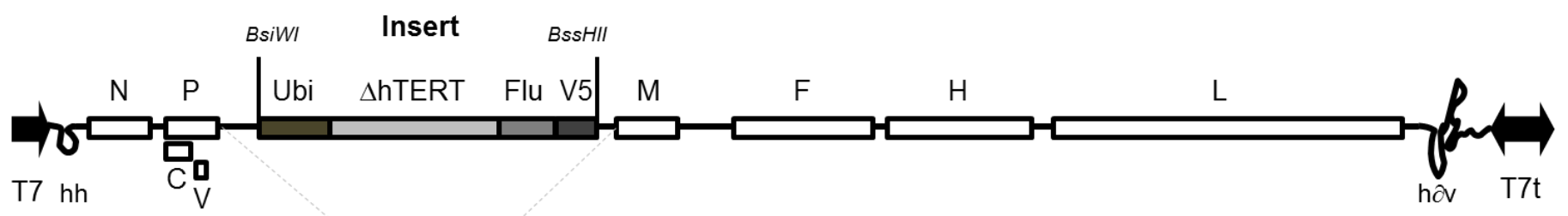

ATU

b

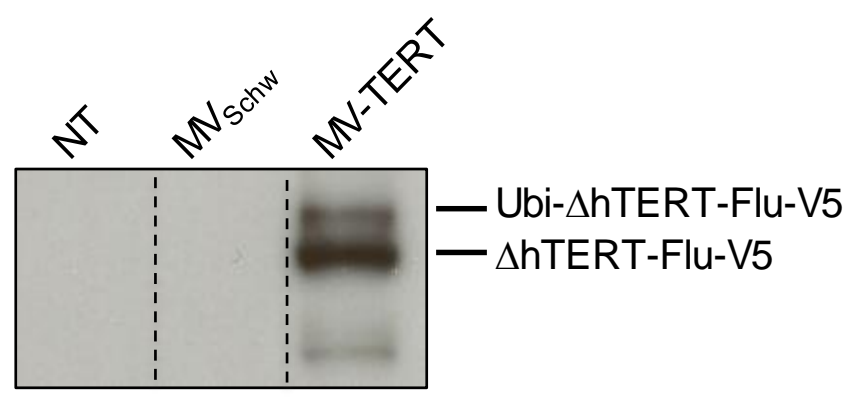

$\left.\begin{array}{lll|l}\hline & & \\ 1 & & 1 \\ \vdots & & 1\end{array}\right]$ Measles Nucleoprotein

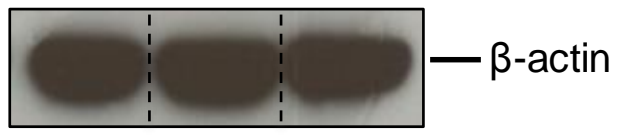


Figure 2

\section{FIGURE 2}

a

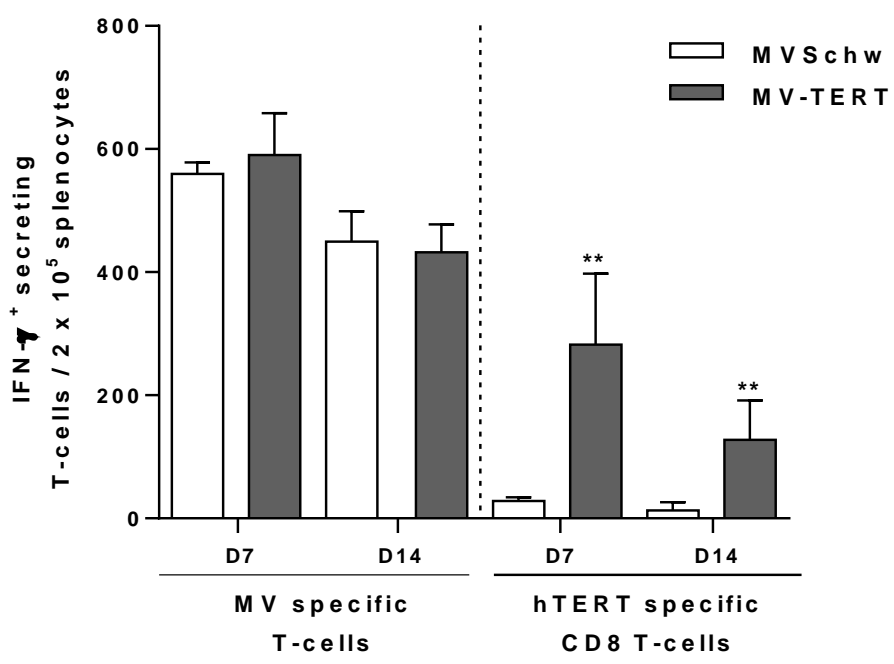

Click here to access/download;Figure;MVTERTsubmitted version Figure 2-Cll.ppt

b HHD/CD46/IFNAR mice

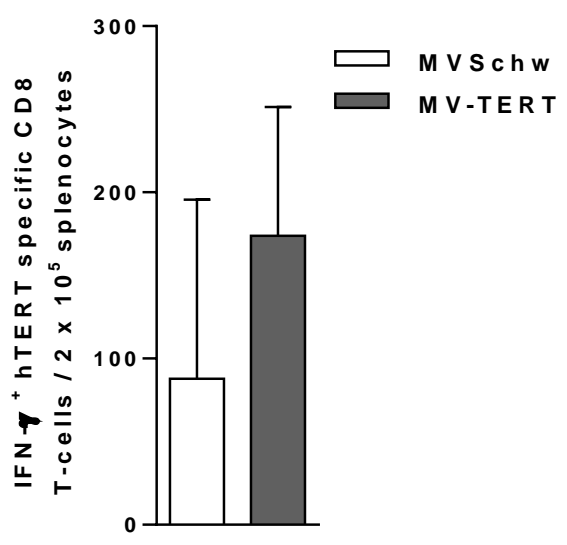

IF N AR/C D $46 \mathrm{~m}$ ice

C

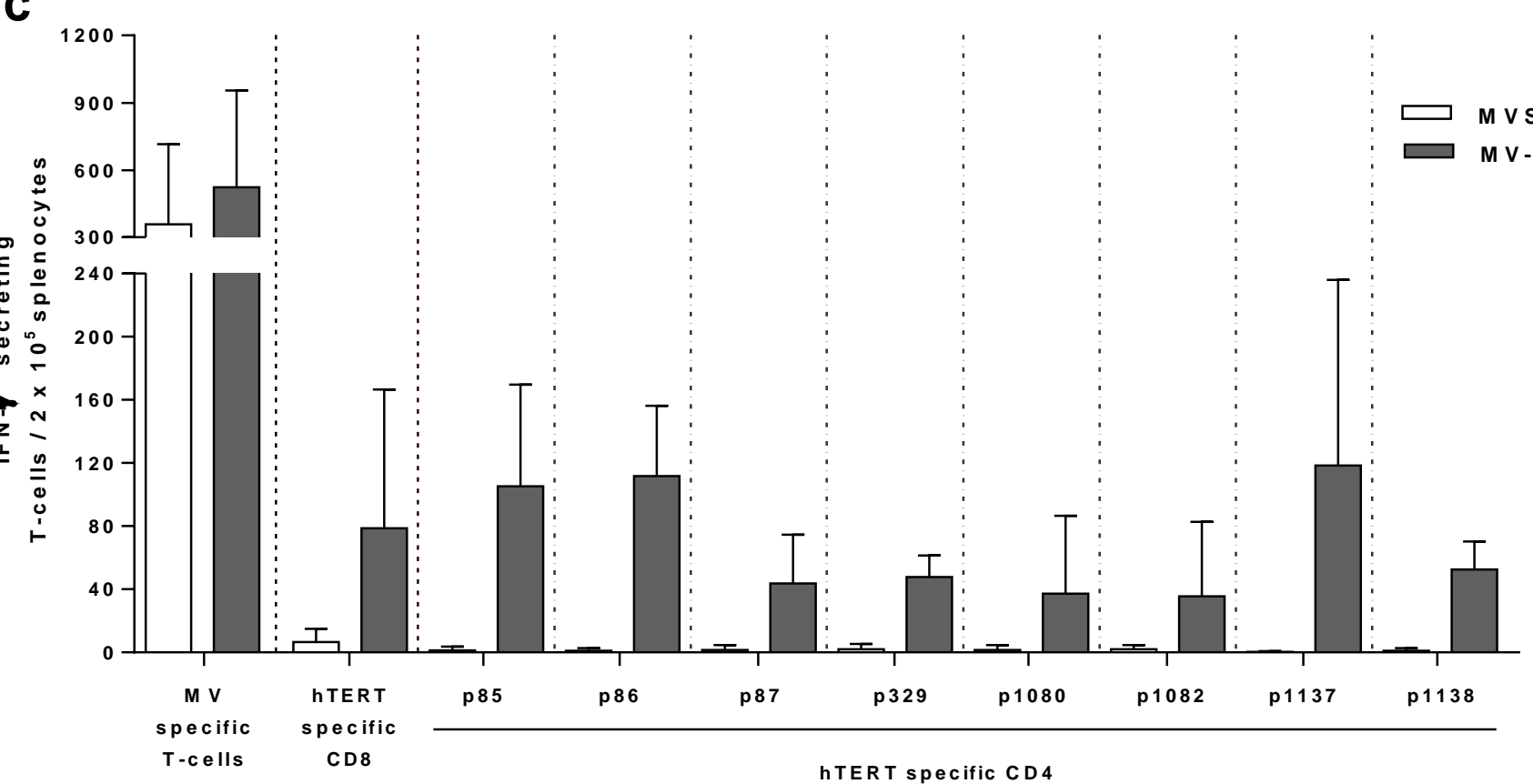

\begin{tabular}{l}
$\sum$ \\
0 \\
0 \\
1 \\
0 \\
0 \\
0 \\
5 \\
0 \\
5 \\
0 \\
0 \\
0 \\
0 \\
0 \\
0 \\
5 \\
0 \\
0 \\
0 \\
0 \\
0 \\
0 \\
0 \\
2 \\
\hline
\end{tabular}
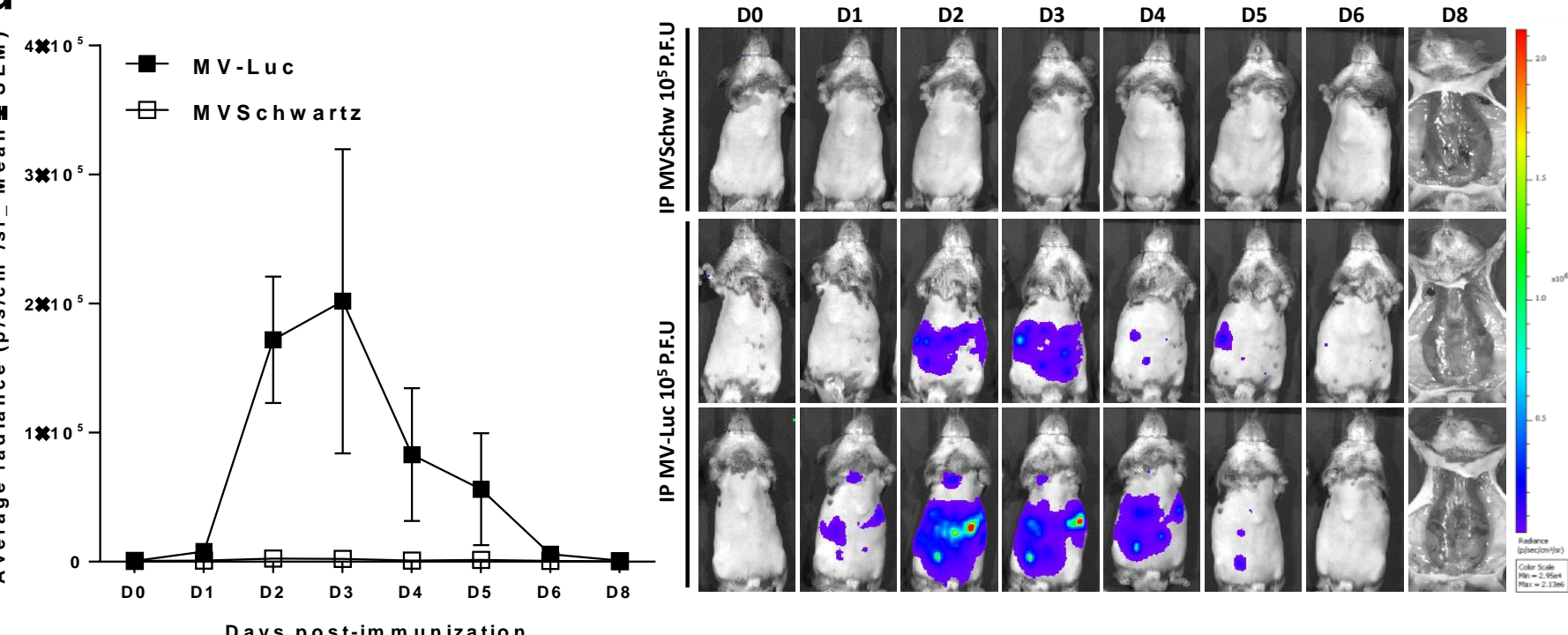
FIGURE 3

a

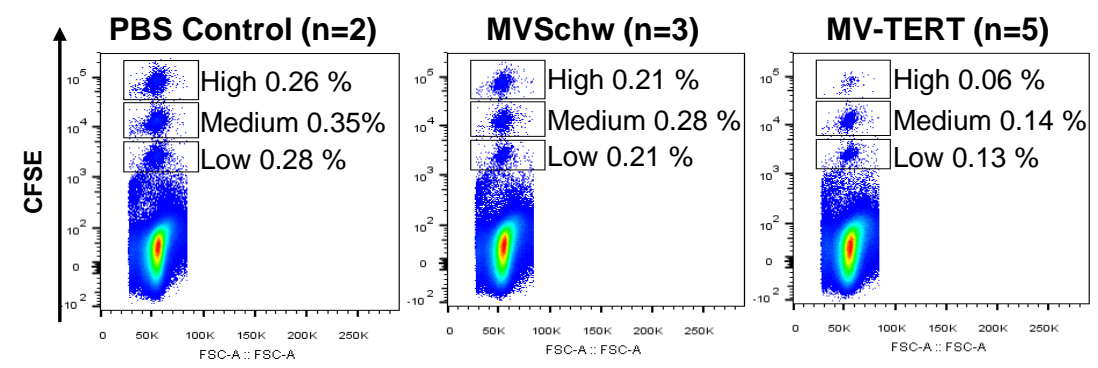

b

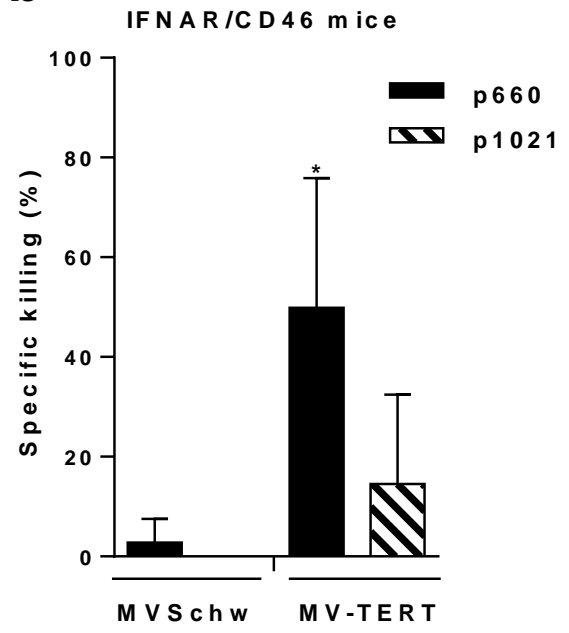


Figure 5

\section{FIGURE 5}

a

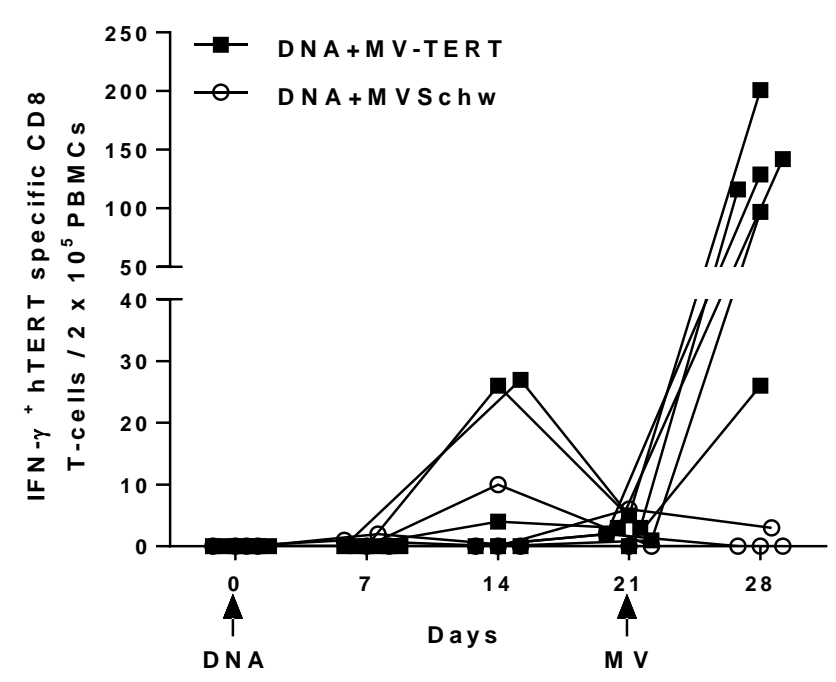

C

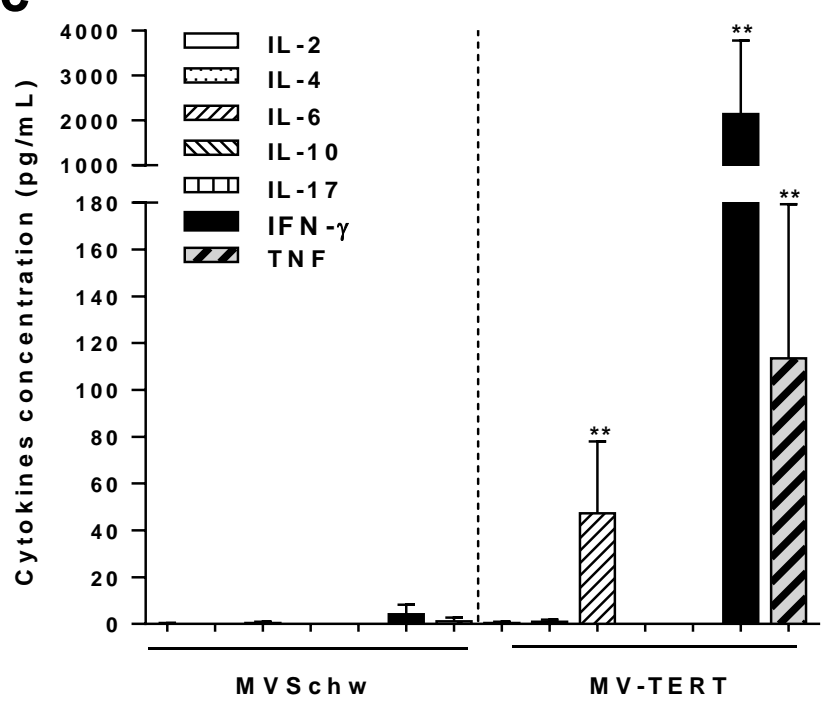

b

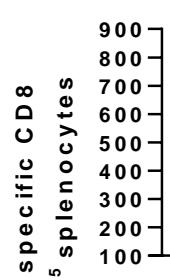

$\begin{array}{ll}0 & 0 \\ \vdash & 0 \\ x & - \\ w & x \\ \vdash & N \\ \pm & - \\ + & 0 \\ 5 & 0 \\ z & 0 \\ = & 1\end{array}$

ZID Prim e

$\square$ Prime-Boost
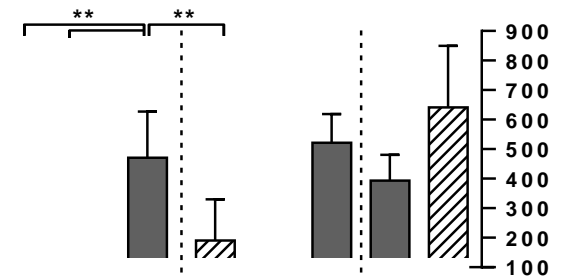

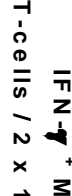

$\overrightarrow{0} 3$ on วิ $\stackrel{5}{5}$

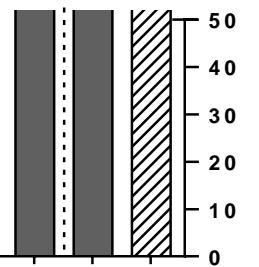
$\infty$

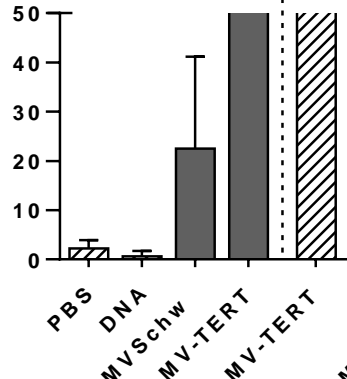
$0 \sin ^{4} 0$

d

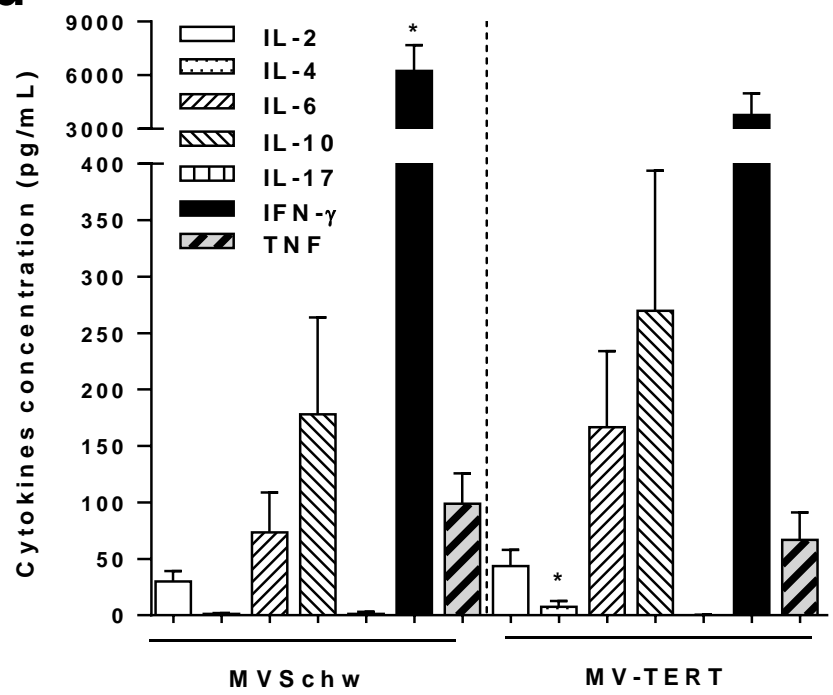

